\title{
Veronica Brady (1929-2015)
}

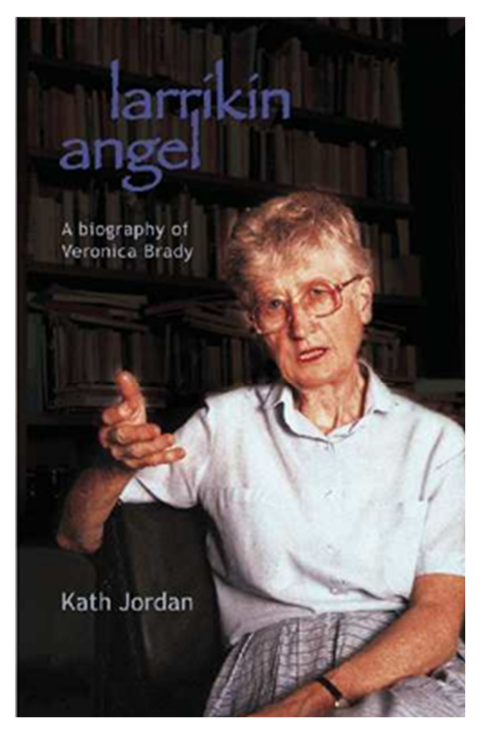

Veronica Brady was born Patricia Mary Brady on 5 January 1929; "Veronica" was the name she adopted when she entered the Loreto order at the age of 21 . It is a teaching order, not a cloistered one, and this suited Veronica Brady admirably; she gained a reputation as a stirring and inspiring teacher, particularly after joining The University of Western Australia in early 1972. With the late Bruce Bennett she championed the introduction of studies in Australian literature, at the time in the face of sometimes stern opposition. There was nothing like stern conservative opposition to get Veronica moving: her ancestors were Irish Catholics and on her mother's side included convicts, so in one sense she always remained true to her roots.

Veronica Brady gained a national and international reputation as a public intellectual, literary critic and tireless moral crusader. She was fearless, a Mother Courage whose causes were her 'children'. That courage often put her at odds with governments or the Church, and drew controversy but also admiration from many people across a wide range of Australian society and overseas. She was a literary commentator whose work was noticed well outside the literary community; she was a Catholic nun who detested the edicts of the conservative popes and who was suspicious of believers whose faith wasn't "tempered with a certain amount of doubt"; she was a feminist by instinct who inspired many women, both old and young. She spoke on philosophical, literary, social and ethical issues not only across Australia but in China, India, Indonesia, Italy, Singapore, Spain, the United Kingdom and other countries for fifty years. She was a white person whom the Aboriginal community trusted, a symbolic figure for many women engaged in Australian literary, 
religious and social studies, and the only literary critic whom Patrick White trusted and admired.

Veronica was the author of distinguished research works, including The Future People: Christianity, Modern Culture and the Future, A Crucible of Prophets: Australians and the Question of God, Playing Catholic: Essays on Four Catholic Plays, the essay collection, Caught in the Draught, and South of My Days: A Biography of Judith Wright, as well as many other essays on Australian literature, religion and the place of Aborigines, women and the church in Australian society. She was diminutive in stature but not in any other respect and, unselfconsciously, a memorable character. As a teacher she was generous, selfless, enthusiastic and thoroughly reliable but those of us who worked with her will always remember her notes: her handwriting had a Daliesque quality and looked like ink dropped through a wine decanter. Once, when we were at lunch, a waiter asked her if she wanted orange juice rather than wine and I will never forget the withering look she gave him; Julie Bishop could only wish for such a death stare! On another occasion she was driving one of the convents' cars when she suddenly lost control, ran off the road and headed towards a pole. Veronica had enough time, she said, to think "Now I'll find out if it's all true". Then, being Veronica, she missed the pole.

Although she worked across many areas, she could be fearless because she was all of a piece: her religious beliefs emphasised the importance of imagination and she found literature the most profound form of imaginative expression. The need for spirituality lay behind her interest in culture generally and she believed in the importance of community, so that her literary essays have a social and political edge and her socio-political essays have culture and spirituality at their centre. It is no accident that she wrote her doctoral thesis on Patrick White and her final book on Judith Wright, two Australian writers of whom the same things could be said. Veronica lived her beliefs; she was no ivory tower academic. Although passionate she was not dogmatic; I once, as a lecturer much junior to her, told her that I had published an essay 
disagreeing with one of hers about White's novel A Fringe of Leaves. She immediately reacted with interest and encouragement; in fact our disagreements increased our friendship. In the "Introduction" to Caught in the Draught she wrote: "For lack of a vision, a people perish" and she worked hard to help Australia to develop a vision of itself.

Apart from her university roles, Veronica provided a good deal of public service, including on the Boards of the Library and Information Service of WA, Fremantle Press and the $A B C$, and she was Chair of the Perth Branch of International PEN, a writers organisation dedicated to freedom of expression. She made herself an interesting life and lived it fully. On her retirement from UWA in 1994, a festschrift was published in her honour titled Tilting at Matilda; it is dedicated to her "in admiration of her exemplary imagination, knowledge and courage". She was there described as a "larrikin angel", and this phrase became the title of her biography, written by Kath Jordan and published in 2009. On its back cover Fred Chaney is quoted as saying "In an often smug and complacent society, we need Veronica Brady and her ilk to remind us to look beyond ourselves. I think Jesus would be OK with her". She's probably testing him out right now. But we'll miss her.

\section{Dennis Haskell}

Westerly Centre, University of WA 